UDC 004.8; 167.5

DOI https://doi.org/10.30970/2078-6999-2019-23-14

\title{
THE THEATRE OF HUMAN SHADOWS IN THE AGE OF ARTIFICIAL INTELLIGENCE
}

\author{
Kseniya Zobenko \\ Odessa I.I. Mechnikova National University \\ Dvoryanskaya str., 2, 65026, Odessa, Ukraine \\ e-mail:zobenko.k@icloud.com
}

The study reviews the changes in human existence that occur in social philosophy in general and in society in particular, in the era of artificial intelligence systems. The demand for philosophical understanding of artificial intelligence systems is determined, first of all, by the severity of the manifestation of ethical issues related to the implementation of modern technological programs. Human, having created an artificial world with the help of technology, becomes its part, a kind of mediator, reconciling naturalness and artificiality in the world, his technicality and naturalness. The study analyzed the question: can modern technology, synthesizing itself with the natural in man, oppose its innate principle? Does a highly intelligent and highly moral being arise as a result of an act of divine creation or as a result of natural evolution and social development? In order to get answers to these questions, it is necessary to determine the options for the origin of man: 1) it is the result of natural evolution and social development - natural; 2) it is a supernatural origin; 3) artificial origin. The idea of creating a creature with artificial consciousness or even a full-fledged humanoid ("Homo Artificialis") [7, p. 156] is inseparable from the idea of the origin of man himself. It is also important to clarify the specifics of the concept of "artificial human" ("artificial intelligence"). Any consciousness is already largely artificial, since it is fundamentally influenced by culture and civilization (only a baby is a "natural" being). The further appearance of the living space of mankind depends on the correct understanding and solution of these issues, therefore, the study of the socio-ethical aspects of artificial intelligence systems in the conditions of the technologicalization of life seems more relevant than ever.

Key words: artificial intelligence, digital humanities, humanoid, human being, naturalness.

We are threatened not by the advent of superintelligent machines, but by the appearance of defectively thinking human beings. H. Dreyfus ${ }^{1}$ [2, p. 186]

Introduction. Now we live in an era of the introduction of artificial intelligence systems in everyday human activities; we live in an information civilization with its fundamental changes in the technological field. And we meet two sides of the impact of informatization on the development of society, man and nature. Therefore, in search of the element of everyday life that modern society could define, sociocultural researchers returned to the logic of technological progress. But in many concepts, the problem of technological transformations that provoke social changes is not highlighted. Is it possible to exist qualitatively in a system based on various types of interaction (human-machine, inter-machine) without understanding

\footnotetext{
Нам загрожує не пришестя надрозумних машин, а поява неповноцінно мислячих людських істот (Хьюберт Дрейфус).
}

(C) K. Zobenko, 2019 
its essence? Also, the question is in the methodology for studying the specifics of the digital environment, which affects all, without exception, industry and society. The complexity of the study methodology lies in the paradoxical nature of the digital environment as a social construct: does the digital environment simply belong to modernity, while being only one of its dimensions? Or does the digital environment determine the life of a modern person? What is the essence of digital technologies - perhaps they play the role of external extensions of human capabilities, by analogy with the media [3, p. 82-84]; or create a new experience of a person as a creature living in the "being digital" format? Socio-humanitarian researchers are confronted with the immeasurability of the digital environment: what will actually be the starting point of the digital age: the Babbage analytical machine or the abstract Turing machine? How to measure the modernity of the digital environment: perhaps, the degree of user familiarity with the GUI (graphical user interface) or a decrease in the so-called. The digital divide? [6, p. 114, 157]. And is it appropriate now to speak of a shared experience of human existence in digital and non-digital space?

The problem statement. Modern man in his society undergoes transformations and changes during the development of artificial intelligence systems. The speed of technological change naturally leads to the idea that continued technological innovation will greatly affect humanity in the coming decades. The key question for social philosophy, as for every person, is the question: What will be the new experience of a person living in the digital age? What are the consequences for humanity?

A brief overview of publications on the topic. Modern research on the possibility of creating a full-fledged artificial (machine) simulation of human intelligence is possible, thanks to the research of A. Turing in his article "Computing machines and intelligence" (1950). The following problems of artificial intelligence are studied by such foreign scientists as H. Dreyfus "What Computers Can’t Do: The Limits of Artificial Intelligence" (1972), "What Computers Still Can’t Do: A Critique of Artificial Reason" (1992), M. Prensky "Digital natives, digital immigrants” (2001), Nick Bostrom "Superintelligence: Paths, Dangers, Strategies” (2014), J. Searle "Minds, Brains and Programs" (1980), M. Minsky "The Emotion Machine: Commonsense Thinking, Artificial Intelligence, and the Future of the Human Mind" (2006). With the aspiration of how technical and technological achievements developed, transformations of social being under their influence also took place. And these mechanisms of transformation of human social life were given close attention by such authors as N. Wiener "Cybernetics, Second Edition: or the Control and Communication in the Animal and the Machine" (1989), M. Castells "Networks of Outrage and Hope: Social Movements in the Internet Age" (2012), Jenkins H. et al. "Confronting the challenges of participatory culture: Media education for the $21^{\text {st }}$ century" (2009), Van Dijk J. "The network Society" (2012).

The purpose of study is to outline the main vectors of the development of human being in the digital age in the context of social philosophy, its modifications and challenges.

The material statement. Human, having created an artificial world with the help of technology, becomes directly its part, a kind of mediator, combining naturalness and artificiality in the world, his technicality and naturalness. Human gives rise to technique and technology, opposing nature in order to learn how to live. Technology becomes the basis of human being, its absence implies a non-human, as a creature that does not respond to the external environment. 
But can modern technology, synthesizing itself with the natural in human, oppose its innate principle?

We meet with two sides of the impact of informatization on the development of society, man and nature. The first is positive, the second is negative, causing particular concern. Since informatization enhances the technogenicity of a developing society and the world (equipment, technologies, artificial electromagnetic fields). And at the same time it represents a growing informational element that destroys the established traditions and public order [5, p. 117, 126]. A person can no longer free himself from the influence of the technology he created, it contains not only unlimited possibilities, but also unlimited dangers.

Currently, there is a range of problems that are associated with the development of artificial intelligence systems and determining the implementation of modern technological programs. We can distinguish such as:

- the increasing responsibility of subjects (developers) of artificial intelligence systems;

- the specifics of the ethical choice in the implementation of technological programs of artificial intelligence;

- the need for a social assessment of technical innovation in the field of artificial intelligence.

For example, research in the field of bioengineering allows you to create living organisms in artificial conditions, modify the human body, and this, in turn, actualizes the question, which in philosophy is one of the central: what is life? What can be considered a living organism, provided that it is not the creation of human hands?

The further appearance of the living space of humanity depends on the correct understanding and solution of these issues, therefore, the study of the socio-ethical aspects of scientific and technical activity in the conditions of the technologicalization of life seems more relevant than ever.

The unconditional and ever-increasing impact of artificial intelligence systems on human life is due to the fact that the development of science and its application in the form of technology transforms the "Homo Sapiens" species formed by evolution. Currently, the question is about finding a concrete historical optimum for the ratio of the technological capabilities of such an impact and the human value system that preserves it as an existing species. Otherwise, the development of science and technology can lead to the denial of human himself, to his transformation into a cyborg [4, p. 198].

The optimum itself is inextricably linked with the decision, firstly, within the framework of which culture the spectrum of possibilities of the impact of artificial intelligence systems on human life is considered. Secondly, within the framework of which problem is the impact of a historically limited form of absolute ethical values on the degree of impact of artificial intelligence on human life, whose value is determined by the existing specific culture. Since artificial intelligence systems are one of the most important parts of a society's culture, providing a sociocultural communication process (including a social institution providing this process) [6, p. 198-199] the search for this optimum is related to the specifics of the sociocultural environment of modern man. It is necessary to successfully solve the "AI control problem" [1, p. 97-99]. The solution might involve instilling the superintelligence with goals that are compatible with human survival and well-being. 
The idea of creating a creature with artificial consciousness or even a full-fledged humanoid ("Homo Artificialis") [7, p. 47] is inseparable from the idea of the origin of man himself. Has human emerged as a highly intelligent, highly moral being through an act of divine creation or, as a result of natural evolution and social development? I admit some variations of the idea of origin:

1. Human came about in a supernatural way, and then the mind can be created only in the same way - supernatural.

2. Human is the result of natural evolution and social development; these paths are not supernatural, and therefore, can be fully or partially reproduced.

3. Human is the creation of the hands of a more perfect being than man himself. A more perfect being can have supernatural, or natural, or artificial origin. If they themselves were created artificially, these were the hands of an even more perfect being, which, in turn, could be of a supernatural, natural or artificial origin - and so again and again.

The most promising area for the use of artificial intelligence systems and technologies is the "partnership" of man and machine. Nowadays, the interest of artificial intelligence developers has shifted from creating autonomously functioning systems that independently (or in conditions of limited communication with humans) solve the tasks posed in a real environment - to the creation of human-machine systems that integrate human intellect and the abilities of computing machines that simulate human behavior. There is an opportunity to get around the deadlocks and difficulties that lead to the use of autonomously functioning systems with their unsuitability for solving a certain class of problems, by shifting to a person those functions that are not yet available for computers. For its part, a computer system allows you to process large amounts of information, repeatedly view various solutions offered by a person, and provide him with encyclopedic information. Now the informational interaction of a person with a machine is supplemented by the study of the processes of informational interaction between people, mediated by various technical means and technologies of artificial intelligence and aimed at integrating, mutually adapting the intellectual abilities of all participants taking into account their individual tasks, functions, psychophysiological characteristics, conditions and means.

Conclusions. A philosophical understanding of the fundamentally new points introduced by artificial intelligence in various fields of human activity allows us to determine the nature of the forecast of the sociocultural consequences of using artificial intelligence in the scientific and technological development of the world.

A person in his activity, using artificial intelligence in conjunction with other technologies (biotechnology, nanotechnology), creates material that, on a general social level, takes the form of various sociocultural entities: objects (intellectual robots, artificial brain), theoretical concepts and new directions in science (theoretical agents, multi-agent systems and intellectual organizations, virtual technologies), values (moral values associated with computer ethics, which are updated success and artificial intelligence).

Does this mean that specialists in the field of modern humanities who are trying to study the environmental features of the digital environment need to abandon the usual optics of quality research and methodology? Not. But perhaps you should reconfigure your research vision so that the study of the digital environment is not determined in the logic of the struggle of quantitative and qualitative methods, but through interest in the plateau of human capabilities, desires, which 
the digital environment produces. However, today there is a chance to raise the research question in such a way as to analyze everything that the logical-mathematical algorithm that we created can describe. It will be executed by a machine, which in any case, all the time (de) encrypts its messages in what a person can understand. Thanks to this conflict in human and machine communication, users today have at their disposal a graphical user interface. To facilitate the user experience in computer science, a user audio interface is being developed (VUI - voice user interface, Siri example from Apple), as well as a perceptual user interface (PUI - perceptual user interface, based on the integration of visual and auditory perception of gestures and sounds as user teams); in neurobiology, work is underway on the brain-human interface (BCI - brain-computer interface), which greatly simplifies communication with devices for those who have certain physical features. But the responsibility for interpreting the results so far remains with the individual.

\title{
References
}

1. Bostrom Nick. Superintelligence: Paths, Dangers, Strategies. Oxford : University Press, 2014. $352 \mathrm{p}$.

2. Dreyfus Hubert L. What Computers Can't Do: The Limits of Artificial Intelligence. NewYork : Harper\&Row, 1972. 259 p.

3. Confronting the challenges of participatory culture: Media education for the $21^{\text {st }}$ century / H. Jenkins et al. Cambridge : MIT Press, 2009. 129 p.

4. Moody T. Conversation with zombies. Journal of Consciousness studies. 1994. P. 196-200.

5. Prensky M. Digital natives, digital immigrants. On the Horizon (NCB University Press). 2001. Vol. 9. № 5. P. 112-131.

6. Van Dijk J. The network Society. London : Sage Publication Ltd, 2012. 272 p.

7. Vallencien G. Hommo Artificialis. Paris : Michalon, 2017. 208 p.

\section{ТЕАТР ТІНЕЙ ЛЮДИНИ В ЕПОХУ ШТУЧНОГО ІНТЕЛЕКТУ}

\author{
Ксенія Зобенко \\ Одеський національний університет імені I.I. Мечникова \\ вул. Дворянська, 2, 65026, Одеса, Украӥна \\ e-mail: zobenko.k@icloud.com
}

У дослідженні розглядаються зміни в людському існуванні, які відбуваються в соціальній філософії загалом і в суспільстві зокрема, в епоху систем штучного інтелекту. Попит на філософське розуміння систем штучного інтелекту визначається насамперед гостротою прояву етичних питань, пов'язаних із реалізацією сучасних технологічних програм. Людина вже не спроможна звільнитися від впливу створеної нею техніки, яка несе не тільки безмежні можливості, але і безмежні небезпеки. I чимала кількість сучасників належать до категорії «цифрових аборигенів», яким складно уявити наш світ до епохи цифрової культури. Людина, створивши штучний світ за допомогою технології, стає його частиною, своєрідним посередником, узгоджуючи природність і штучність у світі, його технічність та природність.

У дослідженні проаналізовано питання: чи може сучасна технологія, синтезуючи себе із природним у людині, протиставити іiі вродженому принципу? Чи виникає високорозумна і високоморальна істота внаслідок акта божественного творення або внаслідок природної еволюції та соціального розвитку? Для отримання відповідей на ці питання необхідно визначити варіанти походження 
людини: 1) це результат природної еволюції та соціального розвитку - природного; 2) це надприродне походження; 3) штучне походження. Ідея створення істоти зі штучною свідомістю або навіть повноцінного гуманоїда (“Ното Artificialis”) невіддільна від ідеї походження самої людини. Важливо також з'ясувати специфіку поняття «штучна людина» («штучний інтелект»). Будь-яка свідомість вже значною мірою $є$ штучною, оскільки на неї фундаментально впливають культура та цивілізація (лише дитина - це «природна» істота). Подальша поява життєвого простору людства залежить від правильного розуміння та вирішення цих питань, тому вивчення соціально-етичних аспектів систем штучного інтелекту в умовах технологізації життя здається актуальним як ніколи.

Ключові слова: гуманоїд, людина, природність, цифрові гуманітарні науки, штучний інтелект. 